\title{
The mechism of managning the investment attractiveness of regional tourism
}

\author{
Andrey Glotko, Larisa Nyurenberger, Nikita Petrenko*, Natalia Shetinina \\ Novosibirsk State University of Economics and Management (NINH), Russia
}

\begin{abstract}
The article discribes the development of the management system of increasing the investment attractiveness of the regional tourism. In accordance with this objective, the authors have defined the concept of investment attractiveness in the tourism sector. Factors and conditions of the investment attractiveness of the region were determined. The authors considered methodological approaches to the development of the management system of increasing the investment attractiveness of the region. The indicators of investment attractiveness assessment have been studied. The process of managing the investment attractiveness of tourism in mountainous territories has been analyzed. Recommendations have been developed to improve the efficiency of managing the investment attractiveness of the tourism sector in the region.
\end{abstract}

\section{Introduction}

Attracting investment in the tourism sector is one of the major challenges for both government bodies, and business community. The development of the tourism sector in Russia is influenced by global trends, manifested in close cooperation of economic systems and market infrastructure of the regions (Gusakov and Gorbunov, 2004; Endovitsky, 2001).

The struggle for investment resources at different managerial levels points to the need of developing the investment process, facilitating the interaction of its participants as well increasing the investment attractiveness of the tourism sector.

Fund-raising has become one of the most important issues of the regional investment policy. At the moment there is a large number of options for attracting investment to regions with developed projects in the tourism sectors, but it should be noted that not all regions are equally developed and the level of the development of industries in different regions also varies, which indicates that the regions have different investment attractiveness for investors (Zhukov, 2006; Isabekova, 2007; Katasonov, 2005; Korchagin, 2016; Korchagin, 2017).

To attract investment in the local tourism infrastructure, it is necessary to consider the tools for stimulating investment activity.

In order to create favorable conditions for the development of the system for managing investment processes in the tourism sector, it is necessary to understand the scientific

\footnotetext{
* Corresponding author: nepetrenko@ro.ru
} 
validity of management decisions, namely, methods, tools, as well as management functions that will help to form an appropriate level of efficiency.

\section{Methodology}

According to scientific works of most authors, "investment attractiveness" depends mainly on the factors that influence the formation of this attractiveness. Y. S. Tkacheva considers investment attractiveness in the tourism sector as "the expected profitability ratio and investment risks, including the investment climate, investment potential, and investment risks in this concept" (Tkacheva. 2011).

A. Mozgoev believes that "investment attractiveness is determined by a set of properties of the external and internal environment of the investment object that determines the possibility of a boundary transition of investment resources" (Mozgoev, 2002). Investment attractiveness can be considered as a set of different conditions, such as organizational, economic and legal (Semin, 2013). L. G. Akhtarieva believes that " the investment attractiveness of the region is an integral indicator, determined by the combination of its economic and financial indicators, the level of the state, public, legislative, political and social development. Investment attractiveness determines the movement of physical, financial, intellectual and human capital to the country or abroad" (Akhtarieva, 2014.).

V. V. Kiryukhin believes that investment potential and investment risks create investment attractiveness in the tourism sector of the region (Kiryukhin, 2006).

Thus, it should be noted that the approaches to understanding the investment attractiveness are different and the following conclusions can be drawn:

When analyzing the opinions of various authors on the concept of investment attractiveness (Gerashchenko, 2017; Roizman, 2006; Litvinova, 2013; Sevastyanova, 2007), it is necessary to consider it at several levels, such as: state, regional, sectoral, the level of enterprises. In a word, at all levels of the economic system as a whole.

2. Factors: there are external and internal components of investment attractiveness, and they depend on the tourist potential of the region, on its infrastructure, on its socioeconomic development.

3. Investment attractiveness is assessed at all levels of the economic system as a whole within a certain period.

Thus, the investment attractiveness of the tourism sector can characterize the economic benefits of the region, as well as the potential risks of this development (Fig. 1). 


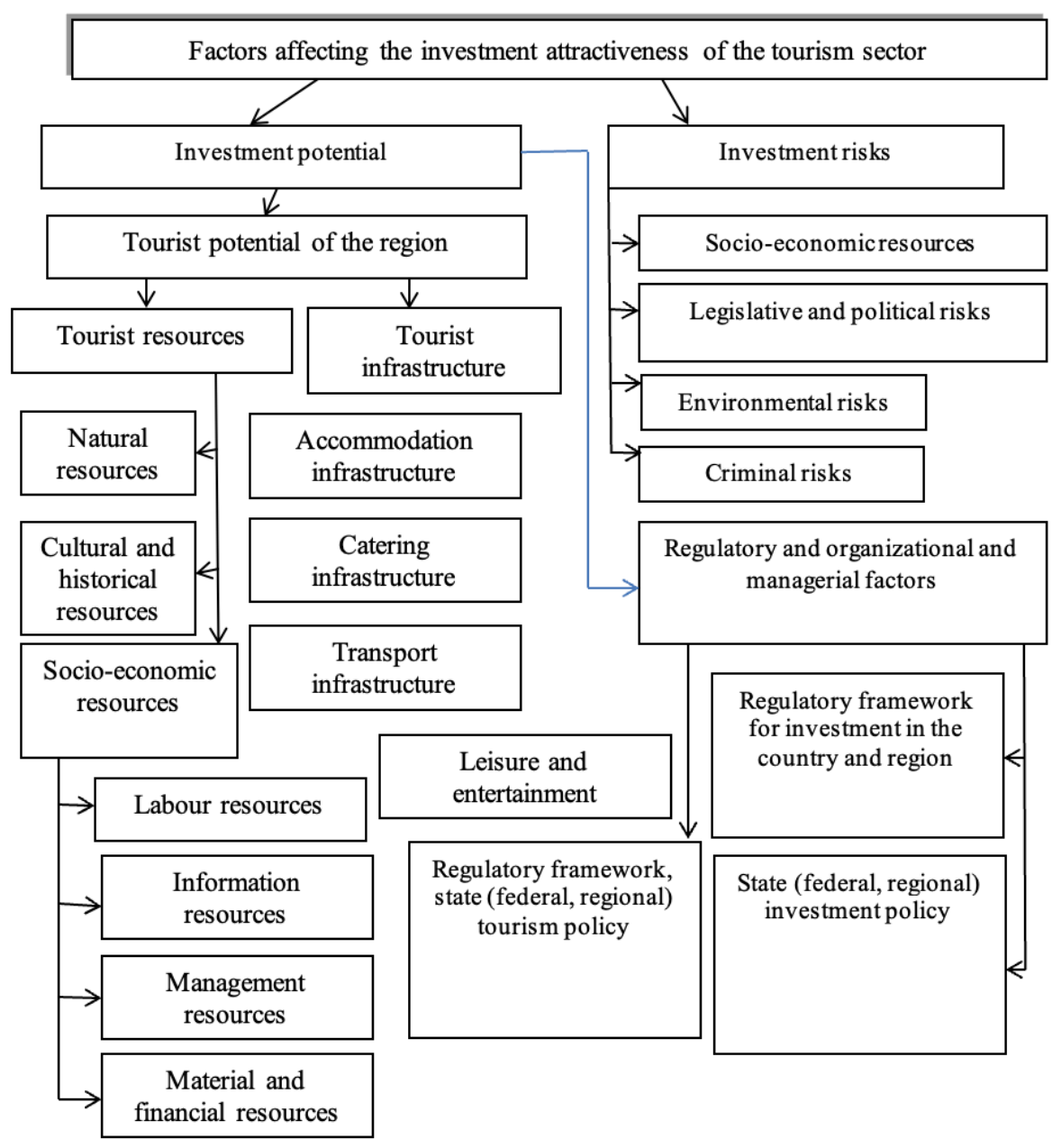

Fig.1. Investment attractiveness of the tourism sector and its factors (compiled by the authors).

Table 1 contains the main indicators of the level of investment attractiveness (compiled according to sources: Abykaev, 2000; Valinurova and Kazakova, 2015; Endovitsky, 2003; Zhukov, 2006; Kotlyar, 1993; Levchenko, 2014).

Table 1. The main indicators of the level of investment attractiveness.

\begin{tabular}{|c|c|}
\hline Analysis & Forecast \\
\hline \multicolumn{2}{|c|}{ Country level } \\
\hline $\begin{array}{l}\text { 1. The phase of cyclical development of the } \\
\text { country's economy. }\end{array}$ & $\begin{array}{l}\text { 1. Forecast for the country's macroeconomic } \\
\text { development. }\end{array}$ \\
\hline $\begin{array}{l}\text { 2. The analysis of macroeconomic indicators } \\
\text { that characterize the investment climate in the } \\
\text { country. }\end{array}$ & $\begin{array}{l}\text { 2. State programs for the development of the } \\
\text { country's economy and specific industries }\end{array}$ \\
\hline $\begin{array}{l}\text { 3. The analysis of indicators characterizing the } \\
\text { investment potential of the country }\end{array}$ & \\
\hline \multicolumn{2}{|c|}{ Regional level } \\
\hline $\begin{array}{l}\text { 1. The rating of the region in the national } \\
\text { economy. } \\
\text { 2. Administrative barriers. } \\
\text { 3. Infrastructure development }\end{array}$ & $\begin{array}{l}\text { 1. The potential of the region. } \\
\text { 2. The level of state support in the region }\end{array}$ \\
\hline
\end{tabular}




\begin{tabular}{|c|c|}
\hline \multicolumn{2}{|c|}{ Industry level } \\
\hline $\begin{array}{l}\text { 1. The phase of cyclical development of the } \\
\text { industry. } \\
\text { 2. Average industry profitability }\end{array}$ & $\begin{array}{l}\text { 1. The potential of the industry. } \\
\text { 2. The level of intra-industry competition. } \\
\text { 3. The level of state support for the industry. }\end{array}$ \\
\hline \multicolumn{2}{|c|}{ Corporate level } \\
\hline $\begin{array}{l}\text { 1. The phase of the enterprise life cycle. } \\
\text { 2. Characteristics of business owners and } \\
\text { managers. } \\
\text { 3. The analysis of financial and economic }\end{array}$ & $\begin{array}{l}\text { 1. Development strategy of the enterprise } \\
\text { starting investment projects. } \\
\text { 2. Forecast of the return on investment projects } \\
\text { of the enterprise by drawing up and ranking the } \\
\text { business plans of these projects }\end{array}$ \\
\hline
\end{tabular}

\section{Results}

The Altai Republic has a diverse historical and cultural potential and unique natural and climatic characteristic facilitating the development of tourism.

The main component of the tourist potential of the region, which determines the opportunities for the development of various types of tourism, is natural resources, which include: location, orographic and climatic conditions, therapeutic, water and biological resources of the region.

The territory of the region is 92.6 thousand $\mathrm{km} 2(1.8 \%$ of the territory of the Siberian Federal District; $0.5 \%$ of the territory of the Russian Federation). The length of the territory from north to south is more than $350 \mathrm{~km}$, from west to east $-400 \mathrm{~km}$.

In the system of mountains of Central Asia and the mountains of Siberia, Altai is distinguished by the richness and originality of the soil cover, the diversity of flora and fauna.

The Altai Republic is currently a major investment platform in recreation and travelling industry. Areas, which are popular with tourists, are being developed, new accomodation facilites are being built. Two and a half hectares of land intended for recreation and culture are mainly occupied by tourism objects, of which $13 \%$ is occupied by existing facilities for recreation and tourism, and several projects of the construction of new modern recreation facilities are being developed now.

Tourism in the Altai Republic is a great support and a sufficient contributor into the economy of our region as a whole. Therefore, it is possible to calculate the cost of the tourist product of the Altai Republic every year, this cost includes the volume of services provided by hotels, camping sites and "green houses", as well as multi-day tourist expeditions, transportation of tourists, skiing, rafting on small vessels. In 2019 the tourist product, in prices of the year, amounted to 4.2 billion rubles compared to 2017 (it was 3.5 billion rubles), increasing by an average of $0.02 \%$ per year.

The share of investments in the tourism sector of the Altai Republic in the total volume of investments in the economy ranges from $6.57 \%$ to $11.12 \%$. In the total volume of investments in the Altai Republic, the share of investments in the tourism sector dropped from $15.1 \%$ in 2014 to $7.27 \%$ in 2018. In 2019, there is an increase in the share of investment in the regional tourism sector in the final volume of investment in the fixed capital of the republic, approximately $17.3 \%$. In comparison, in 2017 , we see an inverse slope, i.e. the share of investments in the region's tourism in the total volume of investments in the fixed capital of the republic decreased to $4.0 \%$. In 2019, the share of investments in the tourism sector in the total investment volume is $11.11 \%$ in the Altai Republic.

Currently, both large and small investment projects in the tourism sector are being implemented in the Altai Republic. At the same time, major investment projects can 
include long-term investment projects, aimed at the construction of large systemically important tourist facilities. In its turn, the concept of small projects can be interpreted as investment projects, not requiring large investments and they can be implemented within a short time. These are mainly investment projects for the construction of small mountain ski resorts, tourist information centers, recreation centers, entertainment centers, camping sites and hotels.

Figure 2 shows the mechanism for increasing the investment attractiveness of the tourism sector in the Altai Republic developed by the authors. The diagram shows the entire step-by-step process of creating and evaluating investment attractiveness.

Let's take a closer look at each stage of this mechanism in order to understand what methods are used for a deeper analysis of investment attractiveness.

At the first stage, more extensive information about investment objects in the region is formed and released. Investment attractiveness is determined at this stage by the level of investment risks, potential and competitiveness of both the region and the investment project separately. Also, at the first stage, information about the supply and demand for investments is collected.

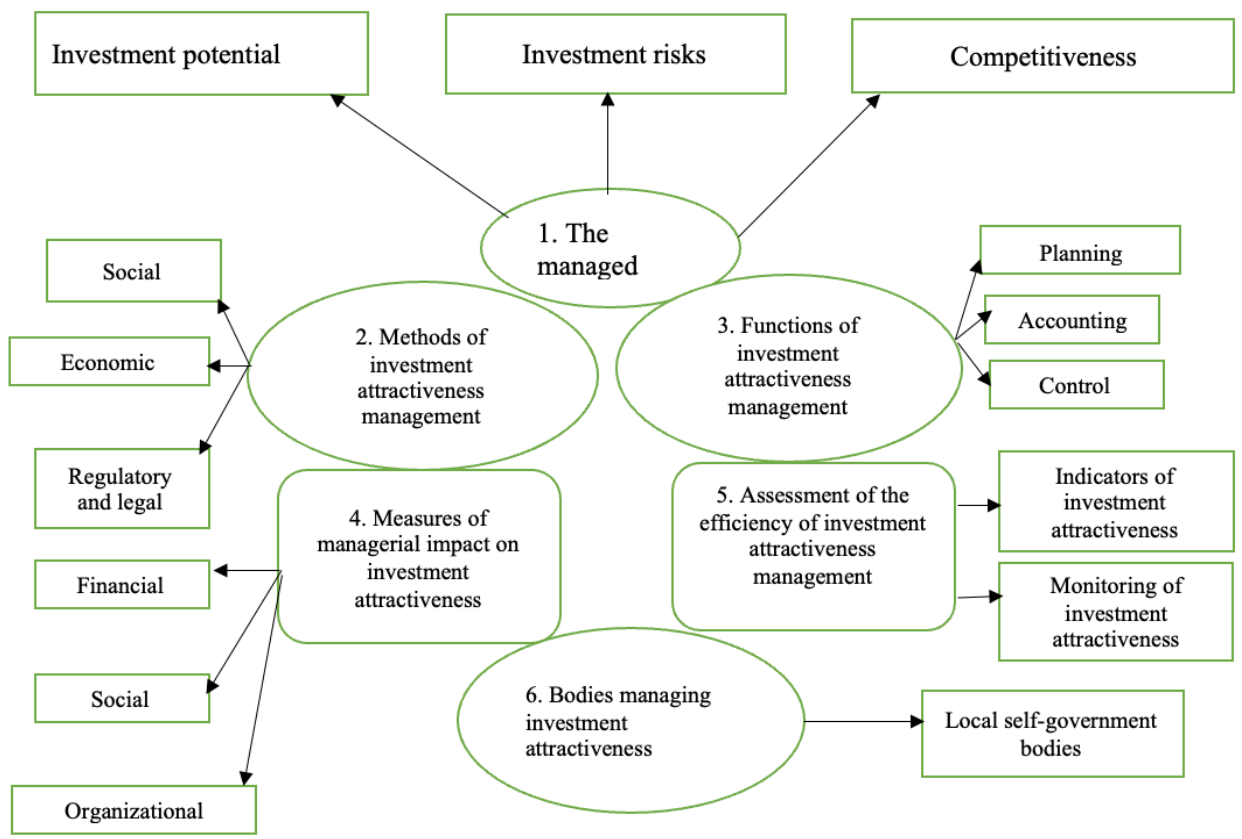

Fig. 2. Mechanism of increasing the investment attractiveness of the tourism sector in the Altai Republic.

At this stage, methods facilitating the access to information on the region are used: direct correspondence with potential investors, collecting and providing information about domestic and foreign markets, holding various events with the involvement of potential investors, as well as informing about the availability of targeted investments in the case of co-financing from the federal and regional budgets.

At the second stage, methods of managing investment attractiveness are developed and tools are formed which will later influence the mechanism development.

Let's take a closer look at the most important methods of increasing the investment attractiveness: 
1) Economic method - with the help of the systematic tools of this method, it is possible to influence the managed businesses. It is necessary to highlight the importance of the costbenefit ratio in order to ensure the positive effect of this method. To increase the investment potential it is necessary to use economic incentives (lending, market pricing, profit, etc.).

2) The social method is about attracting the investment capital to the region, we provide residents with new jobs and improve their living conditions.

3) The regulatory and legal method improves the legislative framework. This increases investments in the best possible way, at the same time it forms a well-established legislative mechanism that provides the legal framework for the entire tourism sector, it regulates issues related to the legislative framework at all stages of managing the investment activity of the region.

At the next stage, such methods such as the development of the region's infrastructure, tax regulation, and state financing will play a special role.

The fourth stage determines the relationship, or we can say that there is a strategic planning for the development of the region and its positioning in the investment market. At this stage, the regional authorities are establishing channels of communication with investors. And they also have the function of monitoring the course of events, namely:

- development and approval, and then the implementation of strategic planning of the regional tourism;

- monitoring the development of favorable conditions for the tour industry;

- assistance in promoting priority areas of tourism in the tourist market;

- organization and holding events in the field of tourism at various levels (municipal, regional), etc.

At the same the management bodies form the investment attractiveness of the Altai Republic.

At the fifth stage, impact measures are determined to manage the investment attractiveness of the region. Three measures or tools of influence were identified, we are going to consider them in more detail. The main organizational tools are the development and adoption of instructions, registration and various administrative procedures. The regulatory tools are contracts, publication of regulatory acts, adoption of state and regional programmes, and compliance with the investment legislation. The financial instruments is the state participation and funding, grants and subsidies, direct project financing, lower taxation, as well as the reduction of bank interest rates.

At the fifth stage, the management of the investment attractiveness of the region is evaluated. Quantitative evaluation criteria can be the size and quality of recreational resources, assessment of the customer base, growth rates, the degree of achievement of the goals set for each group (region, sphere and project), etc.

The standard of living of the population, the human development index, the reputation of an individual company or the region as a whole can serve as the qualitative evaluation criteria.

Nowadays the main task for the tourism based economy regions is to attract investment. But the tourism potential of the region is not always sufficient for a stable and rapid growth of the industry. It should be noted that in order to increase the profitability of the tourism sector, large investments in the infrastructure of the region are required. Since many historical and cultural heritage sites, national parks, and beautiful natural landscapes are located in places with a poorly developed infrastructure. As well as the majority of food service companies and hotel facilities do not meet international standards. Therefore, the task of managing investment attractiveness in the tourism sector remains a priority for the Altai Republic. 
A comprehensive approach to tackling the problem has to be found in order to address this issue, namely:

1. To improve the tools of financial and economic support for investment activities in the tourism sector.

2. To develop the investment activities support system with the help of an information and advisory services.

3. To develop the investment potential of the tourism sector.

4. To improve the investment image of the Altai republic tourism sector.

5. To improve the organizational investment system in the tourism sector of the region.

We will analyse in more detail each proposed option for improving the management of investment attractiveness in the tourism sector of the Altai Republic.

In order to increase investments in tourism, it is necessary to encourage investment activity using various financial and economic support tools:

- creating conditions for reducing the payback period and operational risks;

- changes in regional and local budgets tax revenues, temporary tax exemption;

- changes in the system of tax accounting of income from the tourism sector at a certain level of security;

- reduction of lease payments for land owned by the municipality;

- enabling tourism industry enterprises to obtain loans at a reduced rate.

The next mechanism aimed at increasing the investment attractiveness of the region is the measures to support investment activities with the help of the information and advisory system. This is one of the most important mechanisms, since it is a well-established information system that is able to convey all the abundant and necessary information to potential investors.

With the help of such mechanisms as information and advisory support, favorable conditions for the dissemination of comprehensive and up-to-date information on investment projects, as well as the rules and basic procedures for investment activities in the tourism sector on the territory of the Altai Republic are created.

The following activities lead to the formation of a positive image of the tourism sector: - the promotion of the concept of the tourist brand of the Altai Republic, due to the recreational features of the region;

- activities to promote the image of the tourism sector with the help of advertising companies, fairs, participation in various exhibitions.

When creating a positive image of the tourism sector, it is necessary to create and promote a territorial tourist brand of the Altai Republic. When forming it, it is necessary to take into account the diversity of natural landscapes, a huge number of cultural, historical, archaeological monuments, favorable climatic conditions, rich flora and fauna, and the advantageous geographical location of the region.

It is also important to use effectively the existing communication channels taking into account the target audience while promoting the brand of the region.

But the most important thing today when creating the policy of promoting the tourism sector is the development of an advertising strategy. The advertising strategy may include various promotional activities, but they must adapt to the new realities of the time:

- advertising with versatile modern tools, such as promotion through Instagram, using affiliate marketing with bloggers.

- development and implementation of the annual advertising campaign "Tourist Mountain Altai", which includes consolidated measures to attract tourists and create a favorable image of the region. An advertising campaign should have a thematic focus and provide for the integrated use of various types of advertising materials and options for their placement.

So the investment activity develops more efficiently, it is necessary to use special tools, such as: 
- organizing consulting services for potential investors on all issues of establishing and running a business in the tourism sector of the Altai Republic, including the registration procedures, choosing a construction site, explaining the specifics of Russian and regional legislation in the field of tourism and investment activities, as well as the norms of the taxation system, administrative procedures, etc.;

- the creation of specialized authorized companies on a competitive basis, which provide to investors registration, accounting, auditing, insurance, leasing support services and services on interaction with the tax authorities of the region, etc.;

- the development of measures to minimize the procedural burden for investors and optimization of administrative mechanisms for resolving issues of state support for investments (achieved through the establishment of unified criteria and procedures, under which the investor gets access to state and municipal support for investments). As one of the ways to solve the problem, we can suggest holding investment project competitions based on transparent criteria, or determining industry priorities with a minimum number of other universal criteria, compliance with which provides access to benefits and preferences);

- the creation of a "single window" system that provides investors with service on interrelated areas of investor functioning in one place. Such areas may include taxes, permits, etc.

Thus, increasing the level of investment attractiveness of the tourism sector is a necessary condition for its effective development.

Summing up, we can say that the effectiveness of managing the investment attractiveness of the tourism sector depends on whether this industry is successeful in capital raising, and whether the region is able to develop in tourism sector. It also depends on the management, and we would like to note that most of the tools for achieving investment attractiveness of the region are available or there is an opportunity and potential for their development.

\section{Conclusion}

The development of the tourism sector is influenced by various conditions. Ensuring the investment attractiveness of the tourism sector has a huge impact on the development of tourism.

The investment attractiveness of the tourism sector is understood as a set of characteristics of this sphere that affect the results of investment activity and determine the position of the tourism sector as a subject of investment.

The investment attractiveness of the region is assessed by the two parameters: investment potential and investment risk. Investment potential shows what share the region occupies in the all-Russian market, investment risk shows the scale of certain problems for a potential investor. The total potential consists of private potentials - labour, financial, production, consumer, institutional, infrastructure, natural resource, tourism and innovation. Integral risk consists of private risks: financial, social, managerial, economic, environmental and criminal.

External and internal factors are components of investment attractiveness, and they depend on the tourist potential of the territory, on the infrastructure, on the socio-economic development of the territory.

The main factor influencing the investment attractiveness is the tourist potential of the region. The tourist potential is understood as the whole set of natural, cultural, historical and socio-economic resources, as well as certain factors and conditions necessary for the organization of tourism in a particular territory. The basis of tourist resources are natural, cultural, historical and socio-economic resources. At the same time, socio-economic 
resources are parts of tourism infrastructure, information, labour, financial, and managerial resources, materials and equipment.

Currently, both large investment projects and small investment projects in the tourism sector are being implemented in the Altai Republic. At the same time, major investment projects can include long-term investment projects, aimed at the construction of large systemically important tourist facilities. These are mainly investment projects for the construction of small mountain ski resorts, tourist information centers, recreation centers, entertainment centers, camping sites and hotels.

Thus, we can make a conclusion on how factors affect the investment attractiveness of the tourism sector of the Altai Republic in different ways, and that the region has a sufficiently rich tourist potential that allows developing various types of tourist and recreational activities, and, respectively, determining the level of investment attractiveness of the tourism sector. Along with this, negative factors that can reduce the level of investment attractiveness of the tourism sector of the Altai Republic were mentioned.

The main task for regions where the economy is based on the development of the tourism sector is to attract investment. But the tourism potential of the region is not always sufficient for a stable and rapid growth of the industry. Therefore, the task of managing the investment attractiveness in the tourism sector for the Altai Republic remains a priority.

A comprehensive approach to tackling the problem has to be found in order to address this issue, namely:

- To improve the tools of financial and economic support for investment activities in the tourism sector.

- To develop support for investment activities with the help of an information and consulting system.

- To develop the investment potential of the tourism sector.

- To improve the investment image of the Altai Republic tourism sector.

- To improve the organizational investment system in the tourism sector of the region.

Thus, increasing the level of investment attractiveness of the tourism sector is a necessary condition for its effective development.

Summing up, we can say that the effectiveness of managing the investment attractiveness of the tourism sector depends on whether this industry will be successeful in capital raising, and whether the region will be able to develop in tourism. It also depends on the management, and we would like to note that most of the tools for achieving investment attractiveness of the region are available or there is an opportunity and potential for their development.

\section{References}

1. M. A. Gusakov, A. A. Gorbunov, Regional aspects of innovation and investment activities (2004)

2. D. A. Endovitsky, Integrated and control of investment activity: methodology and practice, Finance and statistics (2001)

3. L. Zhukov, The role of regions in the formation of the investment climate in Russia, Investments in Russia, 7, 8-12 (2006)

4. O.Isabekova, Investment policy and its components, Investments in Russia, 9, 25-30 (2007)

5. V. Yu. Katasonov, Investment potential of the economy: mechanisms of formation and use (2005)

6. Yu. A. Korchagin, Investment strategy (2016) 
7. Yu. A. Korchagin, Modern economy of Russia (2017)

8. Ya. S. Tkacheva, Characteristics of the components of the investment attractiveness of the enterprises of the tourist and recreational complex of the region, Creative economy, 2 (50), 107 (2011). Access mode: http://bgscience.ru/lib/4475/

9. A. Mozgoev, About some terms used in investment processes, Investments in Russia, 6 , 48 (2002)

10. A. N. Semin, Basic directions and tools for increasing the investment attractiveness of the agricultural sector of the economy, The economy of the region, 3, 235 (2013)

11. L. G. Akhtarieva, Modern approaches to assessing the investment attractiveness of regions, Vestnik UGUES. Science, education, economics, 1 (7), 233 (2014)

12. V. V. Kiryukhin, Investment risk in the analysis of investment attractiveness, Problems of modern economy, 3 (19), 5 (2006)

13. E. A. Gerashchenko, Conditions and factors of development of investment attractiveness of the recreational sphere, Modern aspects of economics, 4, 1 (2017)

14. I. Roizman, Modern and promising typology of the investment climate of Russian regions, Investment in Russia, 3, 9 (2006)

15. V. V. Litvinova, Investment attractiveness and investment climate of the region: a monograph (2013)

16. S. A. Sevastyanova, Regional planning of tourism and hotel industry development (2007)

17. N. Abykaev, Investment potential and economic growth, Economist, 6, 58-66 (2000)

18. Burger, Landscapes, tourism, and conservation, The science of the Total Environment (2000)

19. H. Leser (Hrsg.), Diercke Wörterbuch Allgemeine Geographie (1997)

20. H. Neuenfeldt, O. Rose, Stadttourismus als Wirtschaftsfaktor in Aachen. Access mode: www.geogr.uni-goettingen.de

21. J. Swarbrooke, S. Horner, Business travel and Tourism (2001) 